\title{
Two challenges of a selectionist analogy to the theory of selection by consequences
}

\author{
Dois desafios da analogia selecionista à teoria da seleção por \\ consequências
}

Dos desafíos de la analogía selecionista para la teoría de la selección por consecuencias

\section{Luiz Henrique Santana ${ }^{1}$}

[1] Universidade Federal do ABC I Título abreviado: Two challenges to selection by consequences I Endereço para correspondência: Avenida Caminho do Mar, número 1680, apto 02, bloco 02. São Bernardo do Campo-SP. CEP: 09610-000 I Email: santana.luizhenrique@yahoo.com I DOI: 10.18761/pac.2015.6.1.a03 
Resumo: O sistema explicativo desenvolvido por Skinner culminou com a reformulação de um mecanismo explicativo que deveria abordar o comportamento segundo uma analogia entre a seleção natural de Darwin e o condicionamento operante. Skinner defende que esta analogia seria suficiente para ordenar as disciplinas comportamentais em três níveis explicativos: filogenético, ontogenético e cultural. Sem embargo, antes da teoria de Darwin se tornar um paradigma universal para a biologia foi necessário encontrar um substrato sobre o qual a seleção pudesse atuar para assim testar os limites e o alcance da reformulação darwiniana, i.e., as descobertas de Mendel acerca das leis da genética e da transmissão dos caracteres hereditários. Para além da síntese neodarwinista, a Análise Experimental do Comportamento ainda hoje não possui um substrato biológico que permita o teste da hipótese de Skinner sobre a seleção do comportamento operante como um análogo da seleção natural. Tampouco há um modelo matemático para prever a distribuição da variabilidade do repertório individual, em um análogo do princípio de Hardy-Weinberg. Qual o impacto dessas incompatibilidades na teoria da seleção por consequências? Antes de aceitar a analogia entre seleção natural e condicionamento operante é necessário entender as leis da variação e retenção do comportamento e explicar como ocorre essa sensibilidade e como isso afeta o comportamento.

Palavras-chave: condicionamento operante, seleção natural, neodarwinismo, seleção por consequências

Resumen: El sistema explicativo desarrollado por Skinner culminó en la formulación de un mecanismo explicativo que debería abordar el comportamiento según una analogía entre la selección natural de Darwin y el condicionamiento operante. Skinner creía que esta analogía sería suficiente para ordenar las disciplinas conductuales en tres niveles explicativos: filogenético, ontogenético y cultural. Sin embargo, antes de la teoría de Darwin quedarse en un paradigma universal para la biología fue necesario encontrarse un sustrato sobre el cual la selección pudiese actuar para así testar los limites y el alcance da formulación darwiniana, i.e. los descubrimientos de Mendel acerca de las leyes genéticas de la transmisión de caracteres hereditarios. Allá de la sintiese del neodarwinismo, la análisis experimental de la conducta aún hoy non tiene una base biológica que permita el teste de la hipótesis de Skinner acerca de la selección del comportamiento operante como un análogo de le selección natural. Tan poco hay un modelo matemático que permita prever la distribución de la variabilidad del repertorio individual en un análogo de la Ley de Hardy-Weinberg. ¿Cuál es el impacto de estas incompatibilidades sobre la teoría de la selección por consecuencias? Antes de aceptar la analogía entre condicionamiento operante y selección natural, es necesario comprender las leyes de variación y retención del comportamiento y explicar cómo esta sensibilidad ocurre e cómo afecta la conducta

Palabras-clave: Condicionamiento operante, Selección natural, Neodarwinismo, Selección por Consecuencias 


\section{Two selectionists propositions to the science of life and behavior}

Biologists usually consider that - among Darwinian legacies - more important than natural selection is the notion of adaptation (Futuyma, 2009; Mayr, 2004) in order to understand evolution. Although different mechanisms can act upon the evolutionary process of a species (see Nei \& Nozawa, 2011), the concept of adaptation enabled biologists to understanding life as a historical and developmental phenomena.

When Darwin (1859/2013) published his book On the origin of species, his report was filled with descriptions about natural variation among several individuals of the same species, or same populations. He emphasized the relation between differences on morphology and differences on individual behavior (e.g. the different beaks of Galapagos pinches).

However, until the end of his book Darwin (1859/2013) was not capable to explain what is the string of events that may produce morphological and behavioral differences at the same population. He was incapable to explain how variation is created on natural settings and how those differences may be retained by future offspring.

Using an historical analogy, Buhrrus Frederic Skinner $(1953$; 1974) built up a system to explain psychological phenomena by the meanings of behavior. With a philosophical and experimental approach Skinner organized a way to explore the relation between entire organism actions and their consequences on a temporal and spatial related environment.

On a more speculative than experimental moment of his work, Skinner $(1981 ; 1984 ; 1986)$ tried to extend to the study of behavior the seminal principle of evolutionary investigation as used by Darwin (1859). Skinner (1981) believed that this analogy would sort the behavioral disciplines on three explanatory levels: phylogenetic, ontogenetic and cultural.

In the past three decades, behavior analysis has been worked on a model to understand behavioral phenomena with an analogy between natural selection and basic principles of behavior such as operant conditioning (Skinner, 1981; 1984; 1986; Donahoe, Burgos \& Palmer, 1993; Donahoe \& Palmer, 1994; Donahoe, 2012).
Despite the spread of Skinner's selectionist model upon behavior analysis community, the reach of selection by consequences remains inceptive when we take a closer look at other behavioral sciences communities such as ethologists, sociobiologists and neuroscientists for example.

At least part of this restriction is a result of the internal lacks of data and interpretation of the selection by consequences model the way it was presented by Skinner (1981) and other behaviorists (Baum, 2005; Catania, 1998; Pierce \& Cheney, 2004). What are those lacks and what are their impacts upon the theory of selection by consequences? Those are the questions which this essay wants to clarify.

\section{The challenge of substrate}

Before Darwin's theory became a universal paradigm for biology it was necessary to find a substrate on which selection could act in order to test the limits and scope of Darwinian formulation. Gregor J. Mendel's (1865/1996) discoveries and the rediscoveries of Hugo Marie de Vries, Carl Correns and Erich von Tschermak-Seysenegg laws about genetic transmission of hereditary characters were all seminal works that made possible the explanation about the mechanisms of heredity and genetic inheritance (Mayr, 1992; Rheinberger, 2000). Afterwards John B. S. Haldane (1932), Ronald A. Fisher (1930) and Sewall Wright (1931) proposed a unified theory for evolution accounting prospective and retrospective lacks left by Darwin-Wallace theory (Sarkar, 2004).

The Experimental Analysis of Behavior still has not a biological basis for the test of the Skinner hypothesis about the selection of operant behavior as an analogue of natural selection. Although some have proposed theoretical tools to solve the challenge of substrate to the selection of behavior by dealing with a unified principle of reinforcement (Donahoe, Burgos \& Palmer, 1993; Donahoe \& Palmer, 1994), this question remains unsolved. Therefore a unified principle or a single unit for selection demands conclusive data and clarified formulation.

Zilio (2013) reviews some behavioral and neurophysiological considerations about the unified principle of reinforcement. Among his findings are at least two important aspects for a future conclusive formulation of a substrate object for the theory 
of selection by consequences: 1) the definition of an environment-action relation as a unit of analysis; and 2) the proposal of one morphologic and other electrophysiological basis to test the retention of those environment-action relations.

Not just Skinner (1981) but current behavior analysis handbooks define the operant as the unit of selection at the behavioral level (Baum, 2005; Pierce \& Cheney, 2004). An environment-action relation proposal (Donahoe \& Palmer, 1994) was labored to supplement a stimulus-response selection proposal (Skinner, 1984) as a wider way to comprehend behavior. An extension that intends to: $a$. provide a testable unit of analysis; and $b$. describe a string of events (from sensory to motor ones) that compounds behavior as a multilevel phenomenon. Nevertheless the environment-action model still lacks on conclusive data especially when we look for vast meta-analysis.

The substrate challenge could be summarized as the problem of the absence of a material basis for selection. The problem of the substrate refers to the need to identify a biological organ or system capable of facilitating learning and other psychological phenomena. While this problem of mechanism refers to the chain of events underneath the skin that happens in parallel with the behavioral events in order that stimulus function, response and motivating operations depend on the components of the organism sensitive to external and internal variables to the environment.

In other words, although both issues relate to the question of how the body retains the SS relations and SR learned, the problem of the substrate comes to questions like "what are the mediating structures of retention processes and recall of learned relationships? While the problem of the mechanism aims to account the questions: which sequence of events occurs during these same processes? As a way to surpass this, Zilio (2013) assembled two lines of investigation as pathways to test retention mechanisms.

The first one is the morphological changes of synaptic efficacy (Martin, Grimwood \& Morris, 2000; Zilio, 2013) by modifications on the number of dopamine receptors at cell membrane and the proliferation of dendrites terminals. This kind of structural modifications upon the neuron anatomy is highly documented and positively correlated with both procedures of conditioning (respondent and operant) what is usually understood as an evidence for a unified process of learning (Donahoe \& Palmer, 1994).

The second one is an electrophysiological model for synaptic memory, the Long Term Potentiation, LTP, (Morris, 2003; Zilio, 2013). The LTP procedure consists on stimulating a presynaptic neuron with low-frequency electric pulses until we can trace a baseline map of the synaptic electrical interactions, than we start a second phase of presynaptic stimulation with high-frequency pulses till we can observe a significant increase on postsynaptic neuron excitability. The LTP seems to be correlated with glutamatergic system and thus with learning and memory (Riedel, Platt \& Micheau, 2003; Zilio, 2013).

Both lines of investigation proposed by Zilio (2013) seems to suggest some stimulating models to explore the cellular and molecular basis for acquiring, evoking and retaining behavioral relations. However to increase the accuracy of the control and prediction power of behavior analytic theory it is necessary to understand biological variables from a systemic perspective. One of the ways we can reach this systemic view is by delve into electroencephalographic research.

Electroencephalography (EEG) evaluates photovoltaic rhythmic fluctuations in constant time intervals (cycles/second=Hertz) and standardized scale amplitude, microvolts (Teplan, 2002). This technique allows the measurement of neural electrical activity noninvasively and sensitive temporal precision (Teplan, 2002). The EEG enables to investigate the relationship between the occurrences of electric potential variations in the cortical surface simultaneously to learning processes and has been proven to be a valuable class of inner skin events to look upon while intending to explain psychological phenomena such as: self-regulation, attraction and interpersonal relationships, theory of mind and personality (Dickter \& Kieffaber, 2014).

\section{The challenge of mechanism}

It is clear now that when Skinner (1981) proposed the principle of selection by consequences he did not proposed other mechanisms to explain how variation and retention could emerge from a con- 
tingency of reinforcement. And it is also clear that he delegated to biology the responsibility of discovering what happens underneath the organism skin when it behaves (Skinner, 1953; 1974; 1981).

But them how could a behavior analyst know that an action is being reinforced? It seems to be a simple question with a simple answer: if the frequency of this action increases over time after a proximal occurrence of an environmental event, than we could consider this event as a reinforcer and that action as a response, right? Well, it doesn't seem that simple indeed.

If we take this definition into a closer look we may notice that some important aspects of this definition need clarification. What are the criteria to consider some frequency increase as significant? What does this relation between acquisition time and response frequency means to the process of learning? What are the critical parameters to define an environmental event as capable to select a stimulus-response relation?

All of these questions are particularly important to a behavioral system because it's based on their answers that a scientist of behavior can explain how an organism can change his way of act when it is under a environmental challenging situation such as exploring new scenarios, finding food and/or water, learning from group social practices and many other possible situations.

Let us consider a hypothetical situation where we prepared two rats to start lever-press response training. Let us consider that we can program two different operant cages from the same computer in such a manner that both of them will offer exactly the same conditions to both rats (named A and B). After a couple of training sessions we observed that $\mathrm{A}$ is behaving differently from $\mathrm{B}$. With the current theoretical tools we have now, the standard explanation for this inquiry may be that those two organisms respond differently to the environment so that they developed different repertoire. This kind of answer cannot be accepted as a scientific answer of the science of behavior.

A behavior scientist must explain not only in what terms those repertoires are different but also what kind of variables and relations among variables could produce such outcome. This scientist must investigate and describe the event string that may produce differences among organisms' repertoires. It does not matter if those events are something like reinforcement/punishment efficacy, response evocation and variability, discriminative potential of a stimulus or motivational operations.

Behavior analysis has to develop new tools to refine its power of predictability. These new tools must include new data sources (such as under-skin responses) and may include some theoretical ones according to the new findings. These tools will be necessary to approach properly events like aging, pregnancy, intrauterine life, sleep, dreams, sex and many others.

Becoming capable to explain behavior in way where we can define the role played by each of those variables is the only way for us to be able to go back to our imaginary experiment and explain well why A behaves differently from $B$.

That new type of explanation must be as complex as its analogous in biological sciences because it must contain a description of the mechanisms by which behavior is generated, diversified, tested, strengthened, weakened, suppressed, retained, recovered and complexified. Without this, the selectionist analogy will remain an easier path to vague explanations.

\section{Some necessary aspects to look forward}

Before accepting the analogy between operant conditioning and natural selection, it is necessary to understand the laws of variation and retention of behavior. It seems important to recommend behavioral scientists to ask themselves again whether it is enough for a natural science to accept the idea that the body is sensitive to the environment after the reinforcement and not to explain how this sensitivity occurs and how it affects behavior.

Despite the wide spread of behavior analytic tools or techniques among psychopharmacologists, behavioral and cognitive neuroscientists (see Buccafusco, 2009) and other scientists interested on learning and cognition; the behavior analytic system - or its conceptual tools - remains restrictedly used and may be vastly misunderstood (Artzen et al, 2010; Jensen, 2006).

These last challenges maybe someway related to the position of behavior analysis among other 
natural sciences (Marr, 2009) and to the reductionist dilemma between behavior analysis and biology (Marr \& Zilio, 2013). The substrate and mechanism problems were issues originally addressed to the evolutionary theory of Darwin, but - as it is argued in the text - can be extended to selectionist analogy to the theory of behavior. Behavior analysis been criticized since its foundation by its restrictions to the consideration of biological evidence for the explanation of psychological phenomena (Tolman, 1933; 1937; Lorenz 1978; Hebb 1980). However, it may be considered that such restrictions might be justified by the effort to build a science of behavior with self-explanatory independence from physiology (Skinner, 1974). However, by investing in a selectionist model for explanation of behaviour (Skinner, 1981; 1984; Donahoe \& Palmer, 1994; Donahoe, 1996; 2012), behavior analysis imputed to itself the need to cope with the problems arising from the adoption of an explanation based on the selection of behavioral relations.

Some important steps seems to be recently took by some behavior analysts as integrative and clear theoretical analysis has been conducted (Donahoe, 2012; Marr \& Zilio, 2013; Zilio, 2013) in order to propose new pathways of integration between behavior analysis, biology and other natural sciences.

Nevertheless, for a satisfactory level of integration with other natural sciences that may provides supplementary analysis (Donahoe, 1996; Santana \& Seixas, 2012) to behavioral phenomena. Behavior analysts should pursue a way to cross behavioral data with in vivo organism modifications by measuring critical aspects of chemical and electrophysiology (Lucas, Chen \& Richter-Levin, 2013) or by approaching possible retention mechanisms that might occur on epigenetic level (Guan, Xie \& Ding, in press; Lipsky, 2013). Maybe this cross-data analysis could aid the construction of a new unit of analysis beyond the classical operant contingency.

Furthermore, the reach of the theory of selection by consequences is historically linked with the coherence and consistency of radical behaviorism. In addition, radical behaviorism has its own epistemological and ontological questions. Questions sorted from the unclearness and inaccuracy of the distinction between John B. Watson's behaviorism and Skinner's behaviorism (Carvalho
Neto, 2011; Schneider \& Morris, 1987) to the very meaning of the term behaviorism as an appropriate term to describe a fragmented scientific movement (Chiesa, 1994).

Concerning empirical research, behavior analysts could invest on a research position to systematically compares radical behaviorism statements to other behaviorist systems, e.g. hullian and tolmanian neobehaviorisms, Guthrie's contiguity theory, Kantor's interbehaviorism and/or Rachlin teleological behaviorism.

This comparative approach should support an extensive review and refinement of the theory of behavior analysis and simultaneously increase its power of description, falsifiability and prediction. Part of this review is already ongoing (see Ciancia, 1993; Bouchekioua, Molet \& Craddock, 2010; Santana \& Borba, 2015) but it remains restricted to theoretical and historical works instead of experimental designs comparing specific statements or hypothesis.

Scientific systems need direct observations and testability. In terms of life and behavior, we are supposed to check for variation, selection and retention mechanisms. Although we may check for these three dimensions, the scientist of behavior must be based on observations even though it may suggest that the selectionist model is not enough to explain the entire complexity of behavioral phenomena.

As proposed above, the readiness for new discoveries must include: 1) the access and/or development of new data sources for behavior analysis; 2) a unified scope of challenges that may assemble researchers with various backgrounds to engage upon the behavioral sciences enterprise and 3) more predictive and testable systems and theories.

\section{References}

Arntzen, E., Lokke, J., Lokke, G., \& Eilertsen, D. E. (2010). On misconceptions about behavior analysis among university students and teachers. The Psychological Record, 60, 325-336.

Baer, D. M. (1996). On invulnerability of behav-ior-analytic theory to biological research.The Behavior Analyst, 19, 83-84.

Baum, W. M. (2005). Understanding behaviorism: behavior, culture and evolution. 2nd edition. Oxford: Blackwell Publishing. 
Bouchekioua, Y., Molet, M., \& Craddock, P. (2010). Tolman et le Conditionnement Pavlovien. Acta Comportamentalia, 18, 243-255.

Buccafusco, J. J. (2009). Methods of Behavior Analysis in Neuroscience. 2nd edition. Boca Raton, FL: CRC Press.

Carvalho Neto, M. B. (2011). Somos todos behavioristas metodológicos? Boletim Contexto, 35 , 24-30.

Catania, A. C. (1998). Learning. 4th edition. New Jersey: Prentice-Hall.

Chiesa, M. (1994). Radical Behaviorism: The Philosophy and the Science. Boston: Authors Cooperative.

Ciancia, F. (1991). Tolman and Honzik (1930) Revisited or the mazes of psychology (19301980). Psychological Record, 41, 461-472.

Darwin, C. R. (1859). On the origin of species. Retrieved from http://www.gutenberg.org/ ebooks/2009.

Dickter, C. L. Kieffaber, P. D. (2014). EEG Methods for the Psychological Sciences. Los Angeles: SAGE.

Donahoe, J. W., Burgos, J. E., Palmer.D. C. (1993). A selectionist approach to reinforcement. Journal of Experimental Analysis of Behavior, 60, 17-40.

Donahoe, J. W. Palmer, D. C. (1994). Learning and Complex Behavior. Boston: Allyn \& Bacon.

Donahoe, J. W. (1996). On the relation between behavior analysis and biology. The Behavior Analyst, 19, 71-73.

Donahoe, J. W. (2012). Reflections on behavior analysis and evolutionary biology: a selective review of evolution since Darwin - The first 150 years. Edited by M. A. Bell, D. J. Futuyama, W. F. Eanes, \& J. S. Levinton. Journal of Experimental Analysis of Behavior, 97(1), 249-260.

Fischer, R. A. (1930). The Genetical Theory of Natural Selection. Oxford: Clarendon Press.

Futuyma, D. J. (2009). Evolution. 2nd Edition. Sunderland, MA: Sinauer Associates Publishers.

Guan, J. S., Xie, H., Ding, X. (in press). The role of epigenetic regulation in learning and memory. Experimental Neurology.

Haldane, J. (1932). The Causes of Evolution. London: Longmans, Green and Co Ltd.

Hebb, D. O. (1980). Essay on Mind. New Jersey: Lawrence Erlbaum Associates.
Martin, S. J., Grimwood, P. D., \& Morris, R. G. (2000). Synaptic plasticity and memory: an evaluation of the hypothesis. Annual Review of Neuroscience, 23, 649-711.

Jensen, R. (2006). Behaviorism, Latent Learning, and Cognitive Maps: Needed Revisions in Introductory Psychology Textbooks. Behavior Analyst, 29, 187-209.

Lipsky, R. H. (2013). Epigenetic mechanisms regulating learning and long-term memory. International Journal of Developmental Neuroscience, 31, 353-358.

Lorenz, K. (1978). The foundations of ethology. New York: Springer Science.

Lucas, M Chen, A., \& Richter-Levin, G. (2013). Hypothalamic Corticotropin-Releasing Factor is Centrally Involved in Learning Under Moderate Stress. Neuropsychopharmacoly, 38, $1825-1832$.

Marr, M. J. (2009). The Natural Selection: Behavior Analysis and Natural Sciences. European Journal of Behavior Analysis, 10, 103-118.

Marr, M. J., \& Zilio, D. (2013). No Island Entire of Itself: Reductionism and Behavior Analysis. European Journal of Behavior Analysis, 14, 241257.

Mayr, E. (2004). What makes biology unique? Considerations on the autonomy of a scientific discipline. New York: Cambridge University Press.

Mendel, G. J. (1865). Experiments in Plant Hybridization. Retrieved from http://www.esp. org/foundations/genetics/classical/gm-65.pdf.

Morris, R. G. (2003). Long-term potentiation and memory. Philosophical Transactions of the Royal Society of London B Biological Sciences, 358, 643-647.

Nei, M., \& Nosawa, M. (2011). Roles of Mutation and Selection in Speciation: From Hugo de Vries to the Modern Genomic Era. Genome Biology and Evolution, 3, 812-829.

Pierce, W. D., \& Cheney, C. D. (2004). Behavior Analysis and Learning. 3rd edition. Mahwah, NJ: Lawrence Erlbaum Associates.

Rheinberger, H. J. (2000). Mendelian inheritance in Germany between 1900 and 1910: The case of Carl Correns (1864-1933). Comptes rendus de l'Académie des sciences de la vie, 323, 1089-1096. 
Riedel, G., Platt, B., \& Micheau, J. (2003). Glutamate receptors function in learning and memory. Behavior and Brain Research, 140, 1-47.

Santana, L. H., \& Seixas, A. M. F. F. (2012). A psicologia pode ser uma ciência do cérebro? Perspectivas em Análise do Comportamento, 3, 24-31.

Santana, L. H., \& Borba, A. (2015). Edward Chace Tolman e o uso da aprendizagem latente e do reforçamento como princípios explicativos. Acta Comportamentalia, 23, 199-211.

Sarkar, S. (2004). Evolutionary Theory in the 1920's: the nature of the Synthesis. Philosophy of Science, 71, 1215-1226.

Schneider, S. M., \& Morris, E. K. (1987). A history of the term radical behaviorism: from Watson to Skinner. The Behavior Analyst, 10, 27-39.

Skinner, B. F. (1953). Science and Human Behavior. New York: Free Press.

Skinner, B. F. (1974). About Behaviorism. New York: Random House.

Skinner, B. F. (1981). Selection by Consequences. Science, 213(4507), 501-504.

Skinner, B. F. (1984). The Evolution of Behavior. Journal of Experimental Analysis of Behavior, 41, 217-221.

Skinner, B. F. (1986). The Evolution of Verbal Behavior. Journal of Experimental Analysis of Behavior, 45, 115-122.

Skinner, B. F. (1981). Selection by consequences. Science, 213, 501-504.

Skinner, B. F. (1984). The evolution of behavior. Journal of the Experimental Analysis of Behavior, 41, 217-221.

Tolman, E. C. (1966). Sign-Gestalt or Conditioned Reflex. In: Behavior and Psychological Man. Berkeley: University of California Press. (Trabalho publicado originalmente em 1933)

Tolman, E. C. (1966). The acquisition of string pulling by rats - conditioned responses or sign-gestalt? In: Behavior and Psychological Man. Berkeley: University of California Press. (Trabalho publicado originalmente em 1937).

Teplan, M. (2002). Fundamentals of EEG Measurement. Measurement Science Review, 2, 1-11.
Wright, S. (1931). Evolution in Mendelian Populations. Genetics, 16, 97-159.

Zilio, D. (2013). Behavioral Unit of Selection and the Operant-Respondent Distinction: The Role of Neurophysiological Events in Controlling the Verbal Behavior of Theorizing about Behavior. The Psychological Record, 63, 895-918.

\section{Informações do Artigo}

Histórico do artigo:

Submetido em: 4/12/2014

Primeira decisão editorial: 5/09/2015

Aceito em: 5/10/2015

Editor Associado: Candido V. B. B. Pessôa 